\title{
Sistema de nappes Andrelândia, setor oriental: litoestratigrafia e posição estratigráfica
}

\author{
Mario da Costa Campos Neto ${ }^{1}$, Valdecir Assis Janasi ${ }^{1}$, Miguel Angelo Stipp Basei ${ }^{1}$ \& \\ Oswaldo Siga $\mathrm{Jr}^{\mathrm{l}}$
}

\begin{abstract}
Resumo O Sistema de Nappes Andrelândia representa um segmento crustal subductado sob a Placa Paranapanema (Nappe Socorro-Guaxupé) e alóctone sobre o Sistema de Cavalgamentos Carrancas, margem passiva da Placa Sanfranciscana. O setor oriental desse sistema de nappes admite a articulação entre três grandes estruturas transportadas, sub-horizontalmente, para E-NE, contemporâneas a um metamorfismo de alta pressão há ca. $610 \mathrm{Ma}$. A nappe superior (Pouso Alto e klippen associados) é composta de granulitos pelíticos; a Nappe Liberdade é dominantemente pelítica com lascas de retro-eclogitos oriundos de basaltos toleíticos do Criogeniano tardio. A Nappe Andrelândia, inferior, contém 3 formações ao longo de uma coluna litoestratigráfica de espessura aparente mínima de 2400 metros: o Xisto Rio Capivari, basal, dominado por metapelitos; os metawackes do Xisto Santo Antônio, flysch Ediacariano, com área-fonte em arco margmático juvenil; e a seqüência xisto-quartzítica superior do Xisto Serra da Boa Vista.
\end{abstract}

Palavras-chave: sistema de nappes Andrelândia, estratigrafia, litoestratigrafia.

\begin{abstract}
The Andrelândia Nappe System, Oriental Sector: Lithostratigraphy and Stratigraphic Position. The Andrelândia Nappe System represents a crustal segment subducted under the Paranapanema Plate (Socorro-Guaxupé Nappe), which is allochthonous over the passive margin of the Sanfranciscan Plate (the Carrancas Thrust System). Three large structures transported to the E-NE and coeval to high-pressure metamorphism at ca. 610 Ma make up the eastern sector of this nappe system. The upper Pouso Alto Nappe and associated klippen is composed of pelitic granulites, while the Liberdade Nappe is dominantly pelitic and has retro-eclogite slices derived from tholeiitic basalts of Late Criogenian age. The lower Andrelândia Nappe, with $2400 \mathrm{~m}$ minimum apparent thickness, is divided into three formations: the basal Rio Capivari Schist, dominated by metapelites, the Santo Antonio Schist metawackes, an Ediacarean Neoproterozoic flysch having as a source-area a juvenile magmatic arc, and the upper schist-quartzite sequence of the Serra da Boa Vista Schist.
\end{abstract}

Keywords: Andrelândia nappe system, stratigraphy, lithostratigraphy.

INTRODUÇÃO Na construção do empilhamento litoestratigráfico é imprescindível o registro sedimentar de topo e base de estratos originais. A ausência de registro sedimentar dificulta o estabelecimento da polaridade estratigráfica, e apaga as informações coerentes sobre o ambiente de deposição e das seqüências deposicionais. Conceitualmente, uma seqüência deposicional (Vail et al. 1977) representa uma sucessão de estratos relativamente concordantes, geneticamente associados e limitados por discordâncias, ou por descontinuidades desposicionais.

O estudo estratigráfico de unidades litológicas no interior de orógenos, que se encontram estruturadas em pilhas estiradas de nappes sin-metamórficas, submetidas a encurtamento interno (dobramentos isoclinais e sistemas rúpteis de cavalgamentos) e que registram diferentes gradientes de campo metamórfico sob condições extremas de metamorfismo, requer ferramentas indiretas de abordagem metodológica.

O mapeamento geológico de detalhe, a continuidade regional de associações litológicas coerentes quanto ao registro litoquímico, isotópico e metamórfico são importantes alicerces para o reconhecimento de unidades geneticamente associadas (Faure 1977, Nesbitt \& Young 1982, McLennan \& Taylor 1991, Jost et al. 1996).

A espessura das unidades, nos segmentos orogênicos internos, é, no geral, medida a partir da foliação metamórfica (principal superfície de referência) e reflete a espessura da pilha metamórfica e não a espessura estratigráfica da unidade, sobretudo nos extensos domínios monótonos de xistos pelíticos.

O domínio orogênico marginal sul do Cráton do São Francisco, corresponde ao Orógeno Tocantins Meridional (ou Orógeno Brasília Meridional), que registra episódios de subducção e colisão neoproterozóicos, decorrentes do fechamento do paleo-oceano Goianides, quando da convergência da Placa Sanfranciscana sob a Placa Paranapanema (Brito Neves et al. 1999, Campos Neto 2000, Mantovani \& Brito Neves 2005).

Este trabalho apresenta uma síntese estratigráfica para segmentos alóctones desse orógeno, em par- 
te oriundos de ambientes tectônicos compatíveis com zona de subducção.

CONTEXTO GEOLÓGICO REGIONAL O Sistema Orogênico Tocantins, na borda sul do Cráton do São Francisco, é caracterizado por uma pilha de nappes, relacionadas à colisão neoproterozóica entre as placas Sanfranciscana (margem passiva) e Paranapanema (margem ativa). Os diferentes ambientes tectônicos dessa pilha alóctone (fig. 1) organizam-se, dos domínios internos (W-SW) aos externos (E-NE), nas estruturas: i- Nappe Socorro-Guaxupé, espessa lasca $(\sim 15 \mathrm{~km}) \mathrm{de}$ crosta continental profunda representada por unidades granulito-granito-migmatíticas oriundas da raiz de arco magmático; ii- Sistema de Nappes Andrelândia, domínio continental subductado é representado por nappes de metassedimentos em fácies anfibolito e granulito de alta pressão, engajados em zona de subducção (Campos Neto \& Caby 1999, 2000); iii- domínio de provável margem continental passiva constituído pelo Sistema de Nappes Carrancas (Trouw et al. 2000) e pela Nappe Lima Duarte (Campos Neto et al. 2004a).

Essas nappes são estruturas dúcteis sin-metamórficas, com removimentação rúptil pós-metamórfica, onde o deslocamento agregado mínimo foi de $300 \mathrm{~km}$. A trajetória cinemática sin-metamórfica foi contínua e em arco anti-horário, com o topo transportado para E no domínio interno, à N-NW no externo. Apesar de um padrão metamórfico regional invertido, o sistema caracteriza-se por alóctonos com distintos campos de gradientes metamórficos, delimitados pelos contatos rúpteis de empurrão ou pelas rampas laterais, resultando em segmentos de distintos ambientes tectônicos.

No sistema de nappes Carrancas (estruturas mapeadas e descritas por Trouw et al. 1982, Trouw et al. 1986, Ribeiro et al. 1995, Trouw et al. 2000, 2002a, b, Ribeiro et al. 2002a, b, Paciullo et al. 2003) prevalece um padrão metamórfico inverso no interior de cada escama, onde se descreve a sucessão de fases mineraisíndice de um gradiente de campo metamórfico barroviano (cloritóide $\rightarrow$ estaurolita $\rightarrow$ cianita $\rightarrow$ sillimanita; Ribeiro \& Heilbron 1982, Heilbron 1985). Os metapelitos do front desse sistema (Serra do Campestre, Itumirim, MG) possuem quartzo-cloritóide-estaurolita zincífera-cianita-fengita, indicando condições metamórficas de $\mathrm{T} \sim 500^{\circ} \mathrm{C}$ e $\mathrm{P} \sim 7,5 \mathrm{kbar}$, enquanto que os micaxistos a cianita-granada-plagioclásio-estaurolita de Madre Deus de Minas atingiram T $\sim 570^{\circ} \mathrm{C}$ e $\mathrm{P} \sim 7,3$ kbar (Campos Neto \& Caby 1999).

A Nappe Lima Duarte consiste de quartzitos e metatexitos, imbricados com ortognaisses, esses, polimetamórficos. Condições metamórficas de temperatura ultra-alta foram registradas na paragênese enstatitasillimanita (Vilela 2000) e por granulitos básicos a clinopiroxênio-granada-quartzo que atingiram $950^{\circ} \mathrm{C}-12$ kbar (Campos Neto et al. 2004a).

Os alóctonos maiores que conformam o setor oriental do sistema de Nappes Andrelândia são: a Nappe Pouso Alto, superior (e klippen Aiuruoca, Carvalhos e Serra da Natureza), a Nappe Liberdade e a Nappe An- drelândia, inferior. Registram metamorfismo de alta pressão, tanto em fácies anfibolito, com retro-eclogitos, quanto em fácies granulito.

Assim, os campos de gradientes metamórficos das nappes desses sistemas são distintos e refletem diferentes ambientes tectônicos, o que dificulta, mesmo havendo repetições de litologias semelhantes, uma proposta litoestratigráfica única, através das nappes, para esse segmento orogênico.

A proposição inicial de Grupo Carrancas e de Grupo Andrelândia, redefinidos por Ribeiro \& Heilbron (1982) e por Trouw et al. (1983), deveria prevalecer sobre a associação de litofácies de uma pilha litoestratigráfica comum do "Ciclo Deposicional Andrelândia" de Ribeiro et al. (1995), ou da "Megasseqüência Andrelândia" de Paciullo et al. (2003).

A litoestratigrafia e a correlação das unidades do setor oriental do sistema de nappes Andrelândia são os objetivos deste trabalho (Fig. 2).

\section{ORGANIZAÇÃO E CINEMÁTICA DE}

NAPPES O segmento oriental do Sistema de Nappes Andrelândia é composto por uma pilha metamórfica, com espessura preservada de cerca de 4.500 metros e configuração geral sub-horizontal. Articula, por meio da foliação metamórfica $S_{2}$, três alóctonos maiores, em lascas coerentes de rochas, onde a deformação por cisalhamento dúctil foi penetrativa por todo o pacote.

A Nappe Pouso Alto e klippen equivalentes expõem rochas metapelíticas de fácies granulito de alta pressão (Trouw et al. 1998), associadas à leucogranitognaisses. Possui uma forma tabular e repousa sobre a Nappe Liberdade, ao longo de um deslocamento mínimo de $100 \mathrm{~km}$ para N45E. Os registros do pico metamórfico encontram-se a $\mathrm{T} \sim 900^{\circ} \mathrm{C}$ e $\mathrm{P} \sim 15$ kbar (Campos Neto et al. 2004a).

A Nappe Liberdade (Trouw et al. 2000) constitui-se de uma seqüência metapelítica, metapsamitos e gnaisses calcissilicáticos subordinados, metamorfisados em fácies anfibolito de alta pressão e contendo lascas de rochas metabásicas retroeclogíticas, associadas a rochas metaultramáficas. É o registro metamórfico de crosta continental soterrada, em zona de subducção, a profundidades mínimas de $60 \mathrm{~km}\left(\mathrm{~T} \sim 680^{\circ} \mathrm{C}\right.$ e $\mathrm{P} \sim 17$ kbar, Campos Neto \& Caby 1999). Ortognaisses constituem a infraestrutura paleoproterozóica e predominam na retaguarda, em domínio de intensa anatexia neoproterozóica (Migmatitos Alagoa) e de intrusões de turmalina leucogranitos a duas micas.

O processo de exumação da Nappe Liberdade foi acompanhado por intenso estiramento e budinagem e por uma pilha de "nappes anticlinais". Essas estruturas, na ausência da polaridade sedimentar, são definidas pelo núcleo ortognáissico-migmatítico de dobras recumbentes, orientadas na direção do transporte e com terminações peri-antiformais mapeadas. Os indicadores cinemáticos sin- $\mathrm{S}_{2}$ (plano-axial das dobras recumbentes) são coerentes com o transporte regional (Fig. 3). Dobramentos recumbentes a inclinados, também orientados na direção do transporte, são vergentes para 


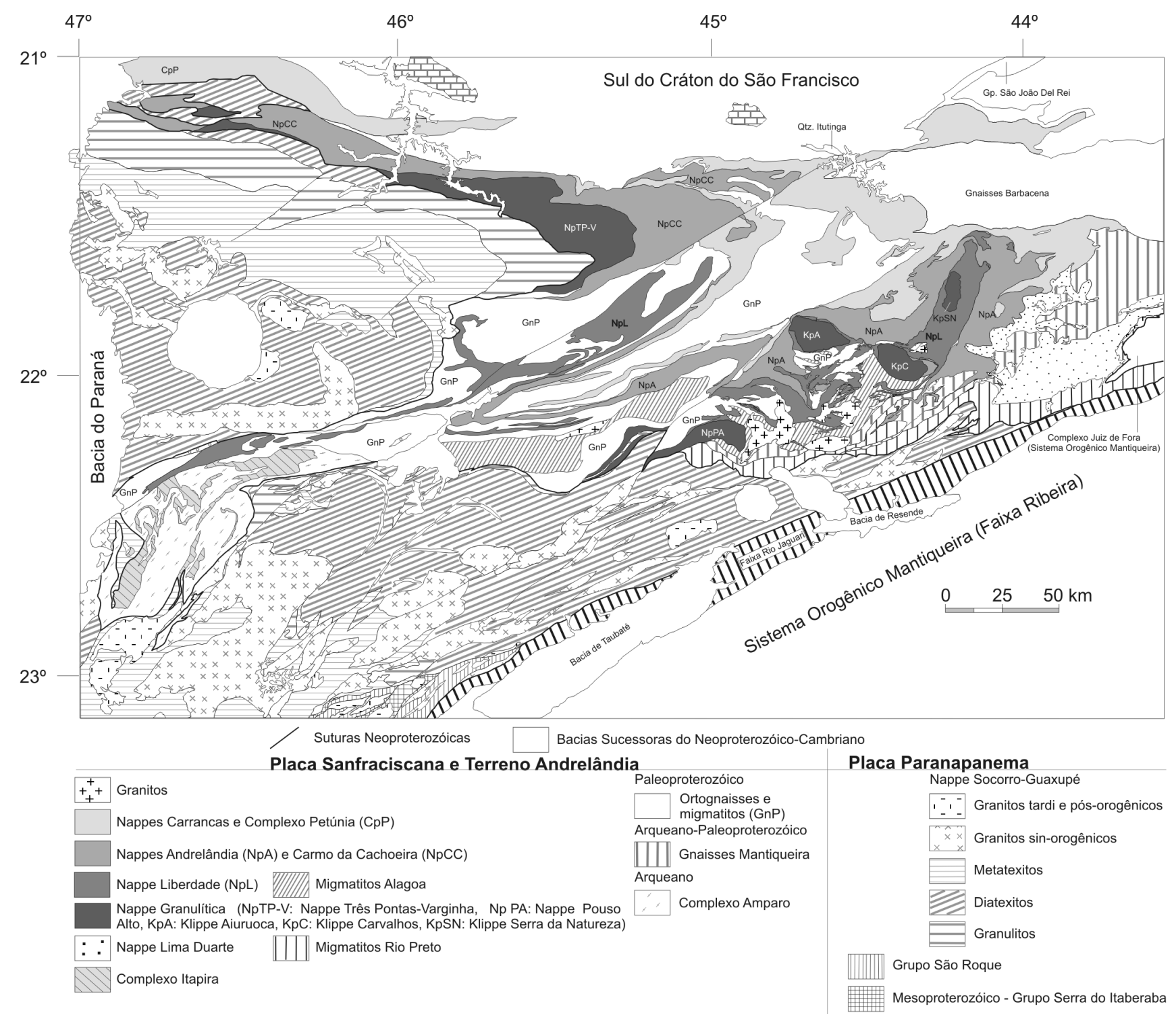

\section{Figura 1 - Mapa Tectônico do Orógeno Brasília Meridional.}

N-NE na retaguarda e para NW no front. Apresentam a xistosidade- $\mathrm{S}_{3}$, de crenulação e/ou bandamento diferenciado, que ocorre como plano axial e que pode estar rompido em sistemas de cavalgamentos com transporte no sentido da vergência. Zonas de cisalhamento, de médio a alto ângulo de mergulho, facilitaram, como rampas laterais, o avanço da Nappe Liberdade. São as zonas de cisalhamento dúcteis sinistrais Caxambu, Rio Piracicaba e Andrelândia Ocidental, no limite oeste da nappe, todas com removimentação rúptil-dúctil dextral (Braga 2002); e a zona de cisalhamento dextral Liberdade-Arantina, no contato leste (Fig. 2), que exibe uma recristalização mineral, sob alta temperatura e em regime de cisalhamento puro (Rodrigues 2003). A cinemática da Nappe Liberdade indica transporte do topo para E-SE na retaguarda, e para NE em direção ao front (Fig. 3). Zonas de cisalhamento normais e sin-metamórficas, orientadas em torno de E-W, promoveram um abatimento da retaguarda. Dessas, a principal estrutura é a zona de cisalhamento Alagoa, normal e com lineações minerais a sillimanita orientadas segundo o mergulho (fig.3). Essas zonas de cisalhamento normais representam, no sistema convergente sin-metamórfico, a alternância com regimes extensionais de deformação. Eles acentuam o adelgaçamento da nappe e facilitam, na sua retaguarda, a entrada do pacote rochoso na zona da sillimanita, por descompressão isotérmica (Santos et al. 2004); enquanto que o front permanece na zona de cianita.

A Nappe Andrelândia (Trouw et al. 2000) define uma fatia, espessa de cerca de $1500 \mathrm{~m}$, no substrato da Nappe Liberdade e repousa, regionalmente, sobre as unidades do Grupo Carrancas (Fig. 2). Caracteriza-se por uma coluna litoestratigrafica coerente, onde predominam metapelitos na base, seguidos por metawackes $\mathrm{e}$ por uma seqüência metapelito-psamítica no topo, submetidos a um pico metamórfico de $\mathrm{T} \sim 680^{\circ} \mathrm{C}$ e $\mathrm{P} \sim 12 \mathrm{kbar}$ (Santos 2004). Na cunha entre as zonas de cisalhamento Caxambu e Rio Piracicaba a Nappe Andrelândia avança para S75E e inflete, a norte, para N35E, onde define 


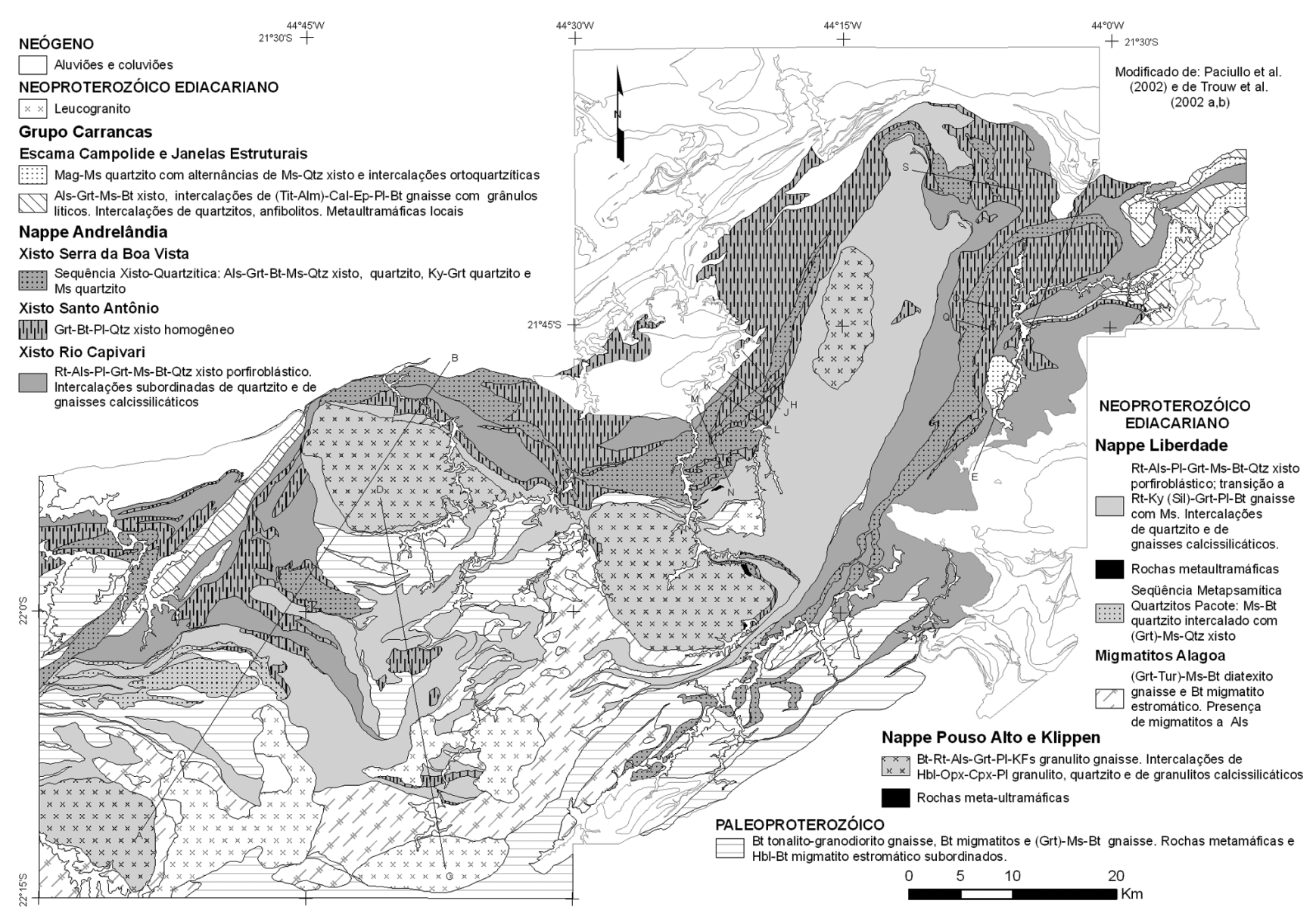

Figura 2 - Mapa Geológico Simplificado do setor oriental do Sistema de Nappes Andrelândia.

o substrato sinformal da calha da Nappe Liberdade. No extremo NE o transporte encurva-se para N50E. Dobras assimétricas recumbentes têm a foliação $\mathrm{S}_{2}$ como plano axial, orientam-se na direção do estiramento e possuem flanco inferior muito curto. Dobras assimétricas, inclinadas e vergentes para N-NW, dobram a foliação $\mathrm{S}_{2}$ e têm $\mathrm{S}_{3}$ como plano axial, muitas vezes rompidos em cavalgamentos transportados no sentido da vergência. $\mathrm{Na}$ Serra de Santo Antônio as dobras da foliação são quase normais, apertadas e com recristalização de fibrolita, configurando um domínio transpressional para a zona de cisalhamento Andrelândia Ocidental.

A Escama Campolide compreende uma seqüência dominantemente metapsamítica entre metapelitos. Estrutura-se em um mega-sinforme recumbente sinmetamórfico. As lineações minerais e de estiramento, no geral orientadas E-W, configuram um padrão bimodal (Fig.4): as lineações minerais indicam um transporte $\sin -\mathrm{S}_{2}$ para N60E, enquanto que, a maioria das lineações de estiramento, é de cavalgamento para N60W, sobre a Nappe Andrelândia. Metapsamitos correlatos ocorrem a sul, em uma janela estrutural sob a Nappe Andrelândia, no antiforme dômico de Souzas (Fig. 3).

A IDADE DO METAMORFISMO Resultados $\mathrm{U}-\mathrm{Pb}$, em monazita, para as rochas do Sistema de Nappes Andrelândia, registram o auge metamórfico $\left(\mathrm{T}_{\text {fechamento }} 600-700^{\circ} \mathrm{C}\right)$. Da Nappe Andrelândia foram analisadas duas amostras do granada-biotita xisto (Xisto Santo Antônio), contendo cristais alongados na forma de grãos de arroz (NESG 695), ou subidioblásticos (AND-XV-126). Os primeiros, coletados em domínio de coexistência entre cianita e sillimanita, indicam idade de $606 \pm 2 \mathrm{Ma}$. A segunda amostra, na zona da cianita, indica uma idade metamórfica de $611 \pm 2 \mathrm{Ma}$ (Fig.5A e 5B, dados analíticos na Tab.1). Da Nappe Liberdade, cristais subidioblásticos de monazita (IBA-VI-37), coletados em cianita-granada-muscovita-biotita xisto, forneceram idade de $611 \pm 18 \mathrm{Ma}$ (Fig.5C e Tab.1), compatível, na margem de erro, com os resultados U$\mathrm{Pb}_{\text {monazita }}$ de Fetter et al. (2001) e Valeriano et al. (2004) e Sm-Nd $d_{\text {granada-rocha total }}$ de Trouw \& Pankhurst (1993).

\section{LITOESTRATIGRAFIA DA NAPPE ANDRELÂN-}

DIA O pacote metamórfico da Nappe Andrelândia é caracterizado por diferentes unidades litológicas, contínuas e mapeáveis regionalmente, coerentes litoestratigraficamente e com os limites estratigráficos (topo e base) desconhecidos. Essas unidades, com status de Formação, são denominadas, da base para o topo, de: Xisto Rio Capivari, Xisto Santo Antônio e Xisto Serra da Boa Vista (Fig.2).

Xisto Rio Capivari Corresponde a monótona série metassedimentar pelítica basal, com espessura preservada do pacote metamórfico de até $750 \mathrm{~m}$ e com inter- 


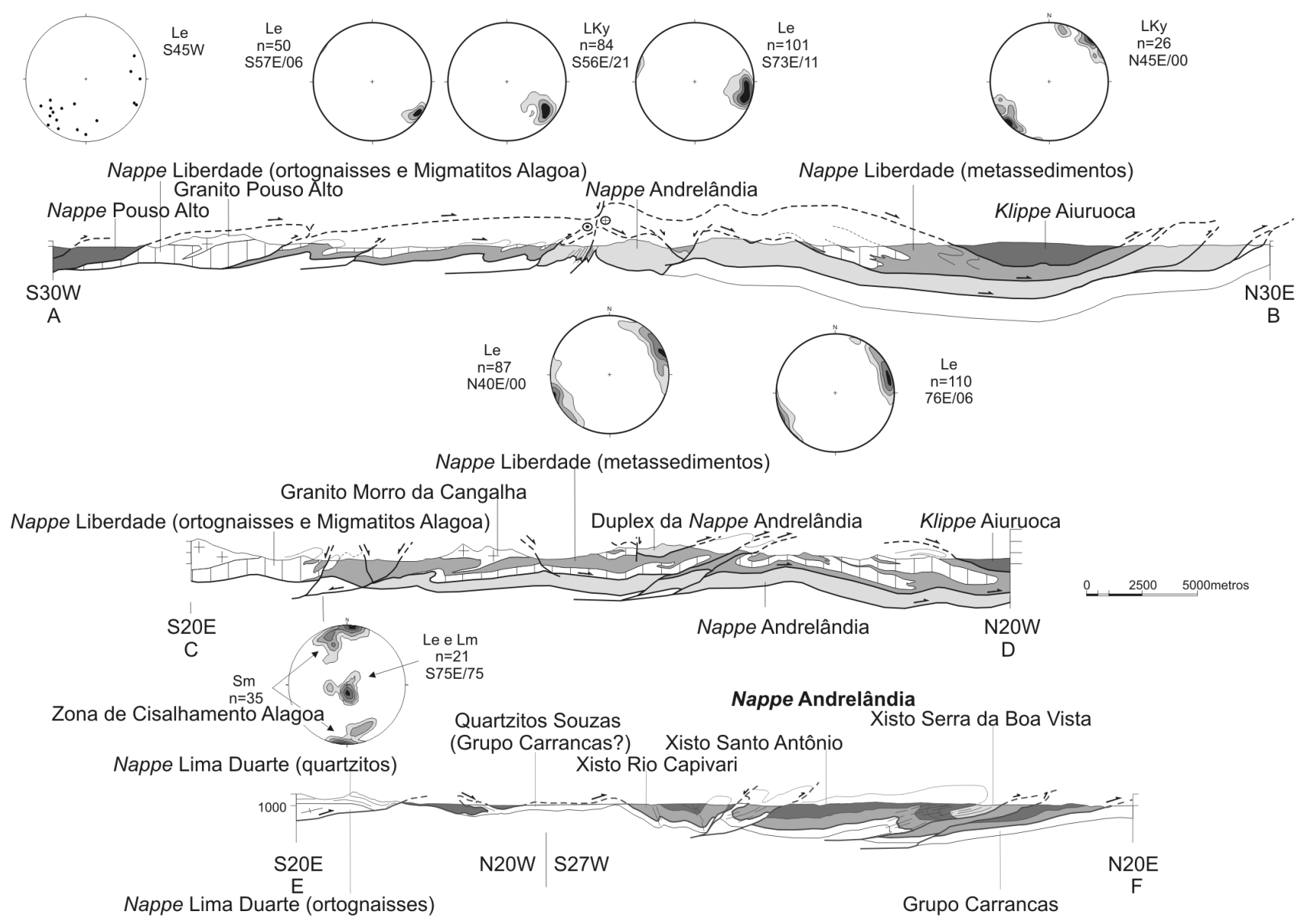

Figura 3 - Seções geológicas no setor oriental do Sistema de Nappes Andrelândia. Localização no mapa da figura 2.

calações esparsas e métricas, de rochas metapsamíticas e metamáficas. São micaxistos porfiroblásticos, com predomínio de biotita sobre a muscovita e com porfiroblastos de granada e de aluminossilicatos (cianita e/ ou sillimanita). O quartzo granoblástico, ou em ribbons, predomina sobre o plagioclásio, que também ocorre em porfirofiroblastos. Ilmenita e rutilo são acessórios freqüentes, tanto na matrix, onde o rutilo pode ocorrer como porfiroblasto decimétrico, quanto inclusos na granada. Localmente a estaurolita está presente na matrix e em relações texturais retrogressivas. Monazita (na matrix ou como inclusões na granada e cianita), zircão e apatita são acessórios. São raras as intercalações de rochas calcissilicáticas que ocorrem, preferencialmente, no segmento oeste da nappe, onde podem intercalar-se leitos de até $5 \mathrm{~m}$ de fels carbonático ( $\sim 50 \%$ de cálcio-esparita e diopsídio, $\sim 40 \%$ de hornblenda, titanita, epidoto e plagioclásio, quartzo e allanita). A base do Xisto Rio Capivari é desconhecida e seu limite inferior corresponde à superfície de deslocamento da nappe (Figs. 6 e 7).

Xisto Santo Antônio (Trouw et al. 1983) É a unidade intermediária que aflora, em lages arredondadas e de cor cinza, por extensas regiões nos segmentos ocidental e norte-oriental da nappe. Na área-tipo (Serra de Santo Antônio) exibe sua espessura aparente máxima ( $\sim 850$
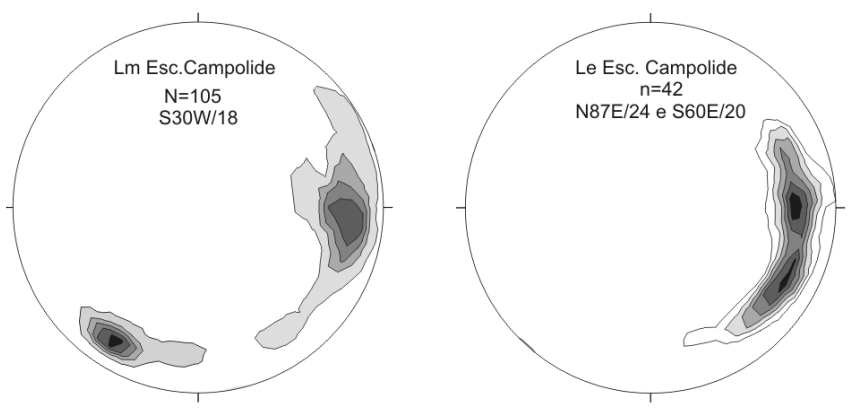

Figura 4 - Padrão bimodal das lineações (mineral $e$ de estiramento) na Escama Campolide ( $N E$ do mapa da figura 2).

$\mathrm{m}$ ), e ocorre em sinformes transpressivos, fortemente inclinados e orientados $\mathrm{S} 28 \mathrm{~W} / 15$, controlados pela zona de cisalhamento lateral Andrelândia Ocidental (Fig.6). Pode ocorrer em janela estrutural sob a Nappe Liberdade e é a unidade que define o duplex da Nappe Andrelândia, em klippen a SE de Aiuruoca-MG, onde a Klippe Pico do Papagaio é a principal estrutura (Figs 2 e 3).

O Xisto Santo Antônio corresponde a metawackes, com intercalações esparsas e pouco espessas de rochas metapsamíticas e metamáficas. O litotipo domi- 
Tabela 1 - Resultados analíticos U-Pb monazita. SPU: número de laboratório; Fração Mag: fração magnética; \#: chumbo radiogênico corrigido para Pb inicial e branco de laboratório; *: valores não corrigidos para brancos e chumbos não radiogênico. Concentrações de U e Pb corrigidas para o branco analítico. Idades (Ma) calculadas com programa ISOPLOT/EX (Ludwig 1999) e constantes de decaimento de Steiger \& Jäger (1977).

\begin{tabular}{l|c|c|c|c|c|c|c|c|c|c|c|c}
\hline Amostra & SPU & $\begin{array}{c}\text { Fração } \\
\text { Mag }\end{array}$ & ${ }^{238} \mathrm{U} /{ }^{206} \mathrm{~Pb}$ & $\begin{array}{c}\text { Erro } \\
(\%)\end{array}$ & $\begin{array}{c}{ }^{207} \mathrm{~Pb} /{ }^{206} \mathrm{~Pb} \\
\#\end{array}$ & $\begin{array}{c}\text { Erro } \\
(\%)\end{array}$ & $\begin{array}{c}206 / 204 \\
*\end{array}$ & $\begin{array}{c}\mathrm{Pb} \\
(\mathrm{ppm})\end{array}$ & $\begin{array}{c}\mathrm{U} \\
(\mathrm{ppm})\end{array}$ & $\begin{array}{c}\text { Peso } \\
(\mathrm{mg})\end{array}$ & $\begin{array}{c}{ }^{238} \mathrm{U} /{ }^{206} \mathrm{~Pb} \\
\mathrm{Idade}(\mathrm{Ma})\end{array}$ & $\begin{array}{c}{ }^{207} \mathrm{~Pb} /{ }^{206} \mathrm{~Pb} \\
\mathrm{Idade}(\mathrm{Ma})\end{array}$ \\
\hline And15-126 & 2925 & A & 10,0493 & 0,486 & 0,060356 & 0,155 & 3870,132 & 2285,9 & 1,0 & 0,001 & 612 & 616 \\
\hline And15-126 & 2926 & B & 10,08348 & 0,475 & 0,05936 & 0,407 & 8325,322 & 1537,5 & 7503,4 & 0,011 & 610 & 580 \\
\hline Nesg 695 & 2913 & A & 10,13694 & 0,483 & 0,060102 & 0,14 & 3890,3 & 941,3 & 4438,2 & 0,011 & 606 & 607 \\
\hline Nesg 695 & 2914 & B & 10,1294 & 0,501 & 0,060641 & 0,204 & 2827,0 & 887,9 & 3998,3 & 0,010 & 607 & 627 \\
\hline Nesg 695 & 2915 & C & 10,04513 & 0,633 & 0,060087 & 0,231 & 3799,8 & 775,2 & 3750,4 & 0,013 & 612 & 607 \\
\hline Iba6-37 & 2918 & B & 10,08998 & 0,502 & 0,060049 & 0,119 & 7723,8 & 1589,0 & 7112,6 & 0,009 & 609 & 605 \\
\hline Iba6-37 & 2919 & C & 10,04847 & 0,467 & 0,060556 & 0,0884 & 3354,8 & 1161,9 & 4515,7 & 0,005 & 612 & 624 \\
\hline
\end{tabular}

nante é um granada-biotita-plagioclásio-quartzo xisto homogêneo, de textura granoblástica e granulação fina a média, no geral equigranular. A biotita, orientada, distribui-se homogeneamentente pela rocha ou define lâminas lepidoblásticas lenticulares. O plagioclásio (oligoclásio-andesina) poligoniza-se equidimensionalmente com o quartzo, ou ocorre como porfiroblastos com nítida zonação química (borda mais rica em anortita). A granada é vermelha e subidioblástica, porfiroblástica ou não é caracteristicamente poiquilobástica, com inclusões orientadas de agulhas de rutilo, em meio a quartzo arredondado, plagioclásio, ilmenita e apatita. Níveis mais ricos em biotita e/ou com muscovita possuem aluminossilicatos (cianita e/ou sillimanita) e estaurolita. Apatita é o mineral acessório dominante e titanita pode ocorrer localmente, na ausência de aluminossilicatos. $\mathrm{Na}$ estrutura homogênea desses xistos destacam-se, com freqüência, lentes decimétricas de quartzo, subparalelas à foliação, algumas das quais oriundas de estágios precoces de fendas de tração. Mg-clorita pode ocorrer na matrix, nos domínios metamórficos de mais baixa temperatura; enquanto que nos domínios de mais alta temperatura e nas klippen, tem-se a segregação de bandas centimétricas brancas, ricas em plagioclásio, ou a geração de leucossomas de composição leuco-tonalítica, envelopados por melanossomas a biotita. Como intercalações subordinadas ocorrem lentes na dezena de metros de anfibolitos nematoblásticos cinza escuros, a hornblenda, plagioclásio e quartzo, localmente a granada; quartzitos a muscovita e granada-muscovitabiotita-plagioclásio gnaisse cinza claro.

Xisto Serra da Boa Vista Ocorre regionalmente no topo do Xisto Santo Antônio, seja no extrado de dobras recumbentes sinfoliais, ou no interior dos sinformes inclinados da foliação (Figs. 6 e 7). Pode repousar sobre Xisto Rio Capivari, no oeste da Serra do Turvo (Fig. 6), ou em Bom Jardim de Minas, sul da Serra da Boa Vista.
A espessura aparente do pacote metamórfico ultrapassa $800 \mathrm{~m}$ (topo sempre desconhecido).

A norte, nas serras Cataguazes e Boa Vista (Fig.7), essa formação possui uma unidade basal metapsamítica, (300 m de espessura aparente), composta por muscovita quartzito e muscovita quartzo xisto, com lentes ortoquartzíticas e intercalações subordinadas de cianita-granada-muscovita-quartzo xistos porfiroblásticos. Os quartzitos micáceos possuem leitos descontínuos (boudins ou lentes) de cianita porfiroblástica em aglomerados de até $30 \mathrm{~cm}$. A unidade superior, que pode estar preservada em uma coluna de $750 \mathrm{~m}$, predomina em direção a SW e é constituída por (clorita)-cianitagranada- biotita-muscovita xisto porfiroblástico, localmente com estaurolita e com porfiroblastos de rutilo (até $10 \mathrm{~cm}$ ). Alternam-se, ritmicamente, com lentes de quartzitos, que podem atingir a centena de metros.

A correlação litoestratigráfica entre as unidades da Nappe Andrelândia e, entre essas e os outros alóctonos, encontra-se expressa na fig. 8 .

UNIDADES DA NAPPE LIBERDADE A pilha da Nappe Liberdade é dominada por metassedimentos pelíticos, onde subordinam fácies de conteúdo pelito-grafitoso, psamo-pelítico, psamítico e wackes. Gnaisses e fels calciossilicáticos são freqüentes, bem como lascas descontínuas e budinadas de rochas metamáficas e metamultramáficas, fels manganesífero (gondito) e ferrífero. A infra-estrutura gnáissico-migmatítica da nappe aflora em seu interior em fatias estiradas e em núcleos antiformais.

Ortognaisses Ocorrem, no interior da estrutura, em fatias contínuas e espessas de até $500 \mathrm{~m}$ e, no front, em lascas de poucas dezenas de metros. São: i) hornblendabiotita gnaisses e biotita gnaisses granodiorito-tonalíticos, leucocráticos, homogêneos e/ou com bandamento conferido por lentes félsicas sub-centimétricas e des- 

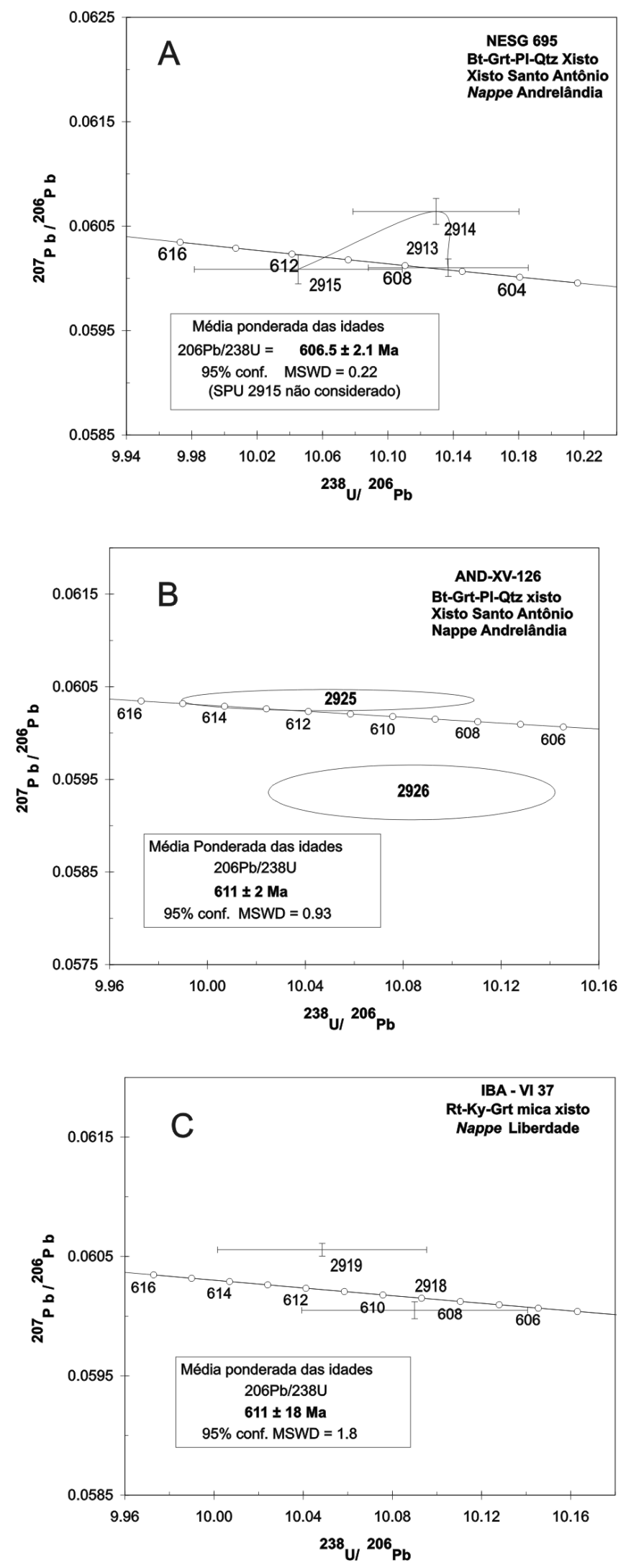

Figura 5 - Diagramas U-Pb em monazita (CPGeo-USP) para xistos das nappes Andrelândia e Liberdadade.

contínuas, ou por bandas de leucossoma estromático; ii) unidade gnáissica decimétrica a metricamente bandada, caracterizada pela alternância de biotita tonalito gnaisses, biotita-hornblenda gnaisses e anfibolitos a biotita, podendo hospedar camadas lenticulares de biotita granito gnaisse porfiroclástico. Possui epidoto, allanita e zircão como acessórios freqüentes; iii) muscovita-biotita gnaisses com granada, de estrutura finamente bandada a estromática; iv) biotita diatexitos cinza-claros, de composição leuco-tonalítica, com estrutura schilieren e enclaves máficos. Constituem unidades de diferentes filiações magmáticas, configurando séries metaluminosas cálcio-alcalina e sub-alcalina, e série peraluminosa. Idades $\mathrm{U}-\mathrm{Pb}_{\text {zircão }}$ definem dois agrupamentos no Paleoproterozóico: o mais antigo a $2120-2140 \mathrm{Ma}$ e o mais jovem a 2050-2100 Ma (Fetter et al. 2001, Campos Neto et al. 2004a, Peternel et al. 2005).

Migmatitos Alagoa Conjunto de rochas diatexíticas e metatexíticas, associadas a corpos de leucogranitos, presentes no sul da nappe (Junho 1993, 1995, Junho $\&$ Mendes 2000). São freqüentes os biotita diatexitos e metatexitos estromático-flebíticos, esses a mesossoma de biotita granodiorito gnaisse cinza biotita-muscovita. Scholens e boudins de anfibolito ocorrem em faixas na dezena de metros. Diatexitos com granada (turmalina, cianita, ou sillimanita), cinza claros, inequigranulares médio e com estruturas schillieren, nebulítica e venulações estromáticas ou dictioníticas, possuem composição granodiorito-tonalítica e gradam a granitos de granulação grossa a muito-grossa. Diatexito estromático definido pela alternância centimétrica de leucossoma branco tonalítico e melanossoma biotítico, também ocorre. Os leucogranitos, freqüentes em diques e soleiras, chegam a corpos tabulares espessos de até $400 \mathrm{~m}$. São granitos e granodioritos hololeucocráticos cinza claros, a muscovita, biotita, turmalina preta e rara granada.

Quartzitos Pacote Muscovita quartzitos brancos, mal acamadados em bancos xistosos, gradam a ortoquartzitos e a muscovita quartzo xistos e chegam a espessuras aparentes de até $200 \mathrm{~m}$. Ocorrem intercalados em micaxistos a granada e sillimanita na retaguarda da nappe, sob ortognaisses, ou sob os Migmatitos Alagoa (Fig.2).

Micaxistos Constitui o pacote metamórfico dominante da Nappe Liberdade, em uma pilha que pode chegar a $3000 \mathrm{~m}$ de espessura. O litotipo principal é um rutilo-(ilmenita-sillimanita)-cianita-granada-plagioclásio-muscovita-biotita xisto porfiroblástico, com textura lepidoblástica e com lâminas lenticulares de um bandamento granoblástico mais rico em quartzo. Grada para termos mais quartzosos e, metamorficamente, para gnaisses, com bandamento félsico a quartzo e plagioclásio, envolvido ou não por melanossoma de biotita. São frequentes os gnaisses calcissilicáticos espessos de até $50 \mathrm{~m}$. Predomina um (granada, rutilo, ilmenita) titanitadiopsídio-hornblenda gnaisse, com bandas a quartzo e plagioclásio e bandas a epidoto, em contatos bruscos ou gradativos com hornblenda-biotita-plagioclásio gnaisse e com biotita gnaisse de granulação fina e homogênea. 


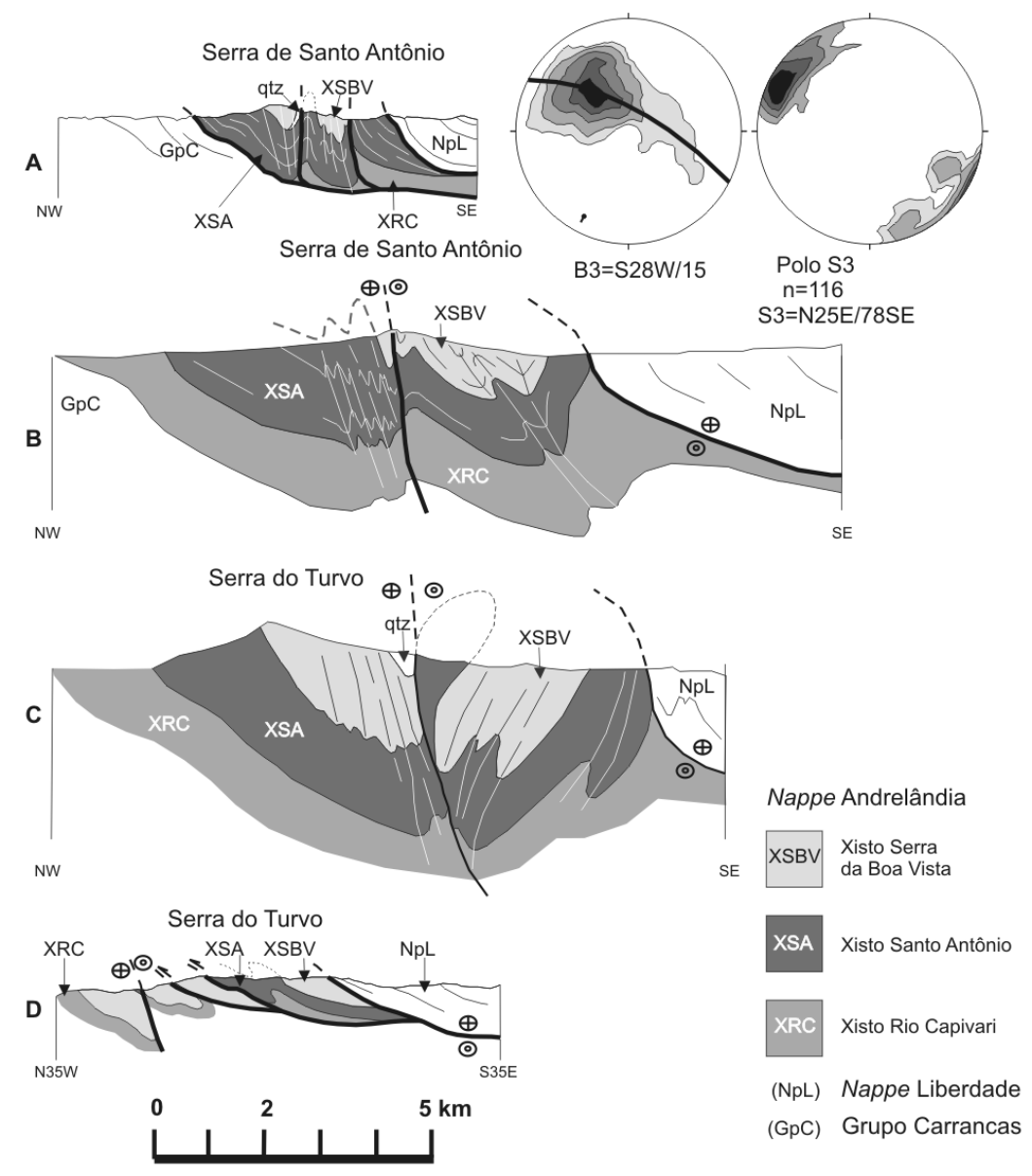

Figura 6 - Seções geológicas no Xisto Santo Antônio na área-tipo, Serra Santo Antônio, sul de Andrelândia-MG. Localização na fig. 2.

Anfibolitos, granada anfibolitos e clinopiroxênio-granada anfibolitos conformam lentes e boudins. Xistos grafitosos, pouco espessos, são repetitivos no front da nappe. Seqüências ferro-manganesíferas ocorrem em corpos métricos de granada-grunerita fels e de gonditos.

Metaultramáficas e Retro-Eclogitos Rochas metaultramáficas pontuais, ou em lentes ovaladas, com espessuras de até $50 \mathrm{~m}$, são freqüentes nas proximidades do contato tectônico basal da nappe. São xistos a talco, clorita e antofilita (relíquias de ortopiroxênio) e clorita-olivina fels. Boudins métricos e lentes na dezena de metros de anfibolitos cinza escuros, com granadas porfiroblásticas $(2-5 \mathrm{~mm})$ emolduradas por plagioclásio coronítico, ocorrem em meio aos xistos, próximos ou não de metaultramáficas e nas seqüências calcissilicáticas. Possuem texturas metamórficas relíqueares, a granada-quartzo-clinopiroxênio, de fácies eclogito a onfacita (Trouw 1992, Campos Neto \& Caby 1999), ou na transição a granulito de alta pressão.

NAPPE POUSO ALTO E KLIPPEN Os metapelitos da Nappe Liberdade exibem uma transição metamórfica à fácies granulito de alta pressão, dado o aparecimento de feldspato potássico (microclina ou ortoclásio pertítico). Essas rochas, no entanto, são do- minantemente alóctones, preservadas no interior de bacias sinformais, em contato brusco (e com truncamentos estruturais) sobre os micaxistos das unidades subjacentes. Ocorrem sobre, ou no front, dos Migmatitos Alagoa (Nappe Pouso Alto e Klippe Carvalhos), ou sobre os micaxistos (Klippen Aiuruoca e Serra da Natureza). São rutilo-cianita-granada-feldspato potássico granulitos, que alternam níveis a plagioclásio e biotita e intercalam quartzitos impuros. Sillimanita ocorre tardiamente e estaurolita aparece inclusa em granada nas klippen. Subordinam-se faixas de granulitos máficos a granada-clinopiroxênio-quartzo, ou a enstatita-granada-hornblenda; granada-biotita-plagioclásio gnaisse e escapolita-hornblenda-biotita gnaisse. Na base da Klippe Carvalhos ocorrem rochas metaultramáficas de fácies granulito, no geral serpentinizadas: espinélio hornblenditos a hogbomita, espinélio harzburgitos a olivina e ortopiroxênio, actinolita websteritos com porfiroblastos de olivina, clino e ortopiroxênio (Almeida \& Junho 1993, Almeida 1993).

ESCAMA CAMPOLIDE (SISTEMA DE NAPPES CARRANCAS?) Sob a Nappe Andrelândia ocorre, em janela estutural dômica na região de Souzas (Fig 3), quartzito branco a muscovita e lâminas de magnetita e, descontinuamente, clorita-muscovita quartzo xisto. Essas rochas são encontradas em dois níveis espessos, 


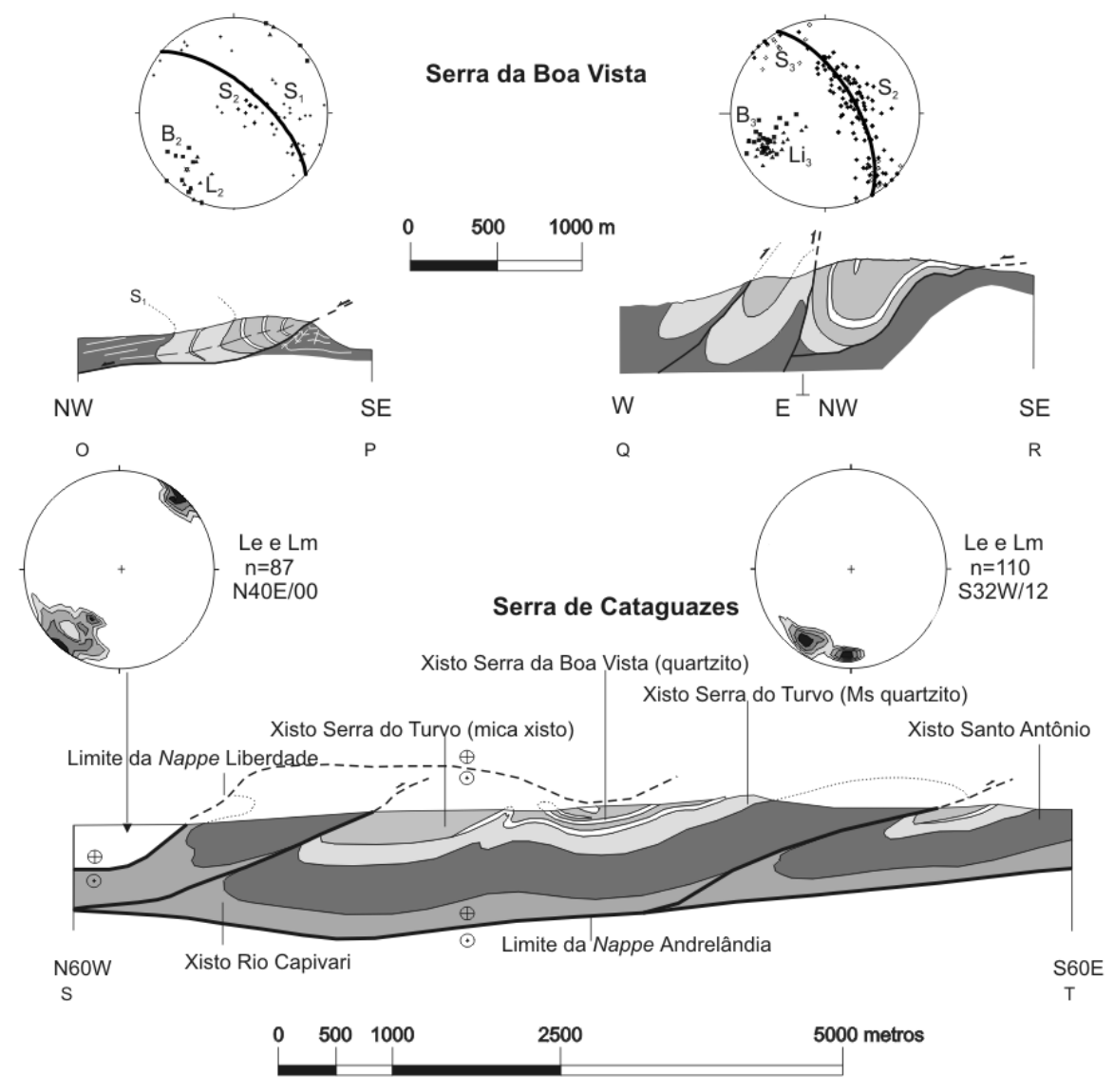

Figura 7 - Seções geológicas no Xisto Serra da Boa Vista na área-tipo, Serra da Boa Vista (E-SE de Andrelândia) e na Serra de Cataguazes (Santana do Garambéu-MG). Localização na figura 2.

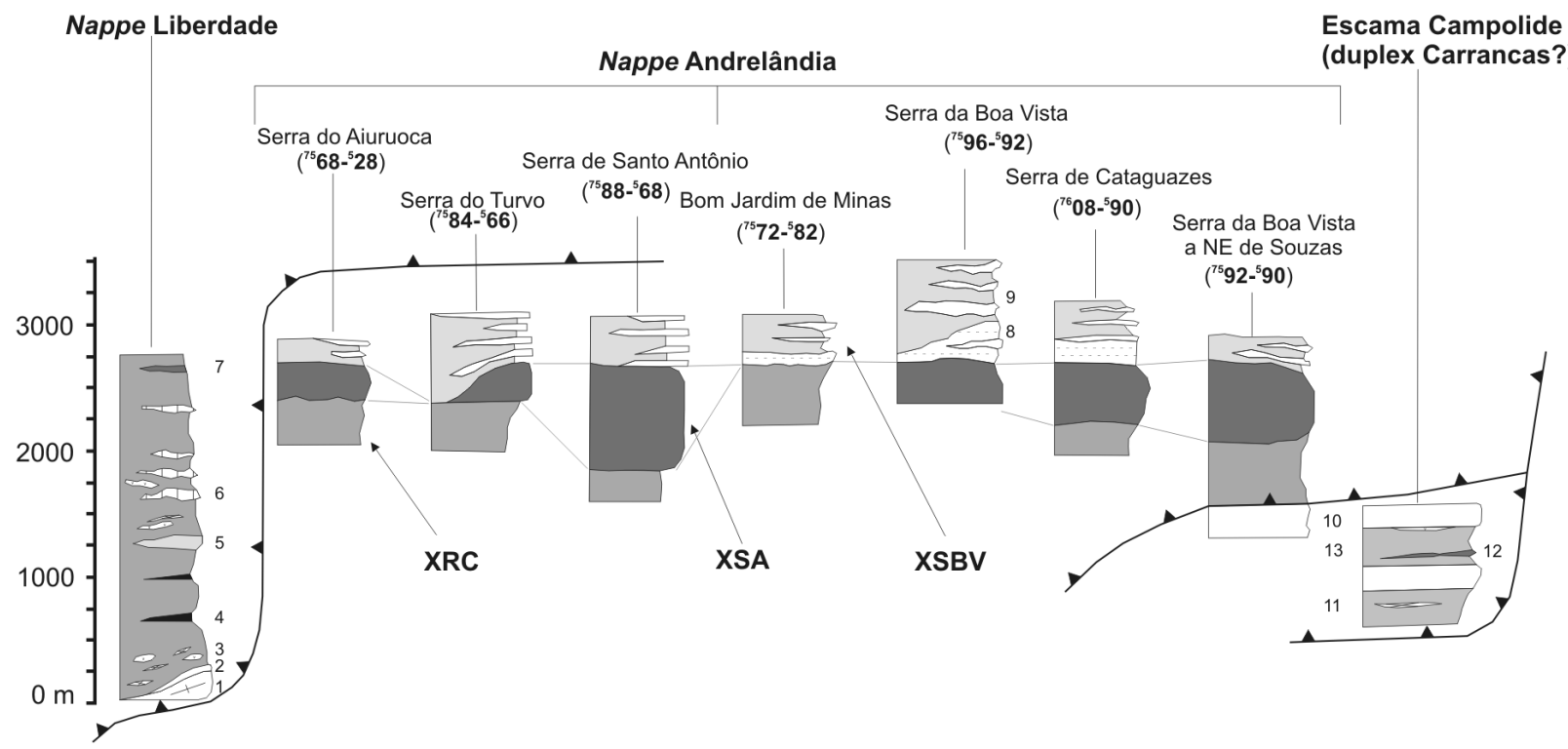

Figura 8 - Quadro de correlação litoestratigráfica. Coordenadas UTM indicam a localização geral das colunas da Nappe Andrelândia.

200m cada, em meio a xistos, cavalgando a Nappe Andrelândia. Os xistos são: a sillimanita-granada-biotita, com finos níveis de granada-biotita xisto, anfibolito e restritos talco tremolita xisto. O conjunto possui $900 \mathrm{~m}$ de espessura aparente que, pela composição e posição na estrutura, sugere um duplex, mais metamórfico, do 
Tabela 2 - Resultados de análises químicas de amostras representativas de metassedimentos das unidades Xisto Rio Capivari (nesg1113a), Xisto Santo Antônio (nesg 1059 el065b), Xisto Serra da Boa Vista (nesg939b e 951a), biotita xisto Carrancas (nesg 1043d e 1228a), Ky granulitos Klippe Aiuruoca (nesg1053a e 1054a) e de retro-eclogitos (CXA 3 e 4) do Sistema de Nappes Andrelândia.

\begin{tabular}{|c|c|c|c|c|c|c|c|c|c|c|c|}
\hline $\begin{array}{l}\text { N. } \\
\text { Campo }\end{array}$ & $\begin{array}{l}\text { NESG } \\
1113 \mathrm{a}\end{array}$ & $\begin{array}{c}\text { NESG } \\
1059\end{array}$ & $\begin{array}{l}\text { NESG } \\
1065 b\end{array}$ & $\begin{array}{c}\text { NESG } \\
939 b\end{array}$ & $\begin{array}{c}\text { NESG } \\
951 \mathrm{a}\end{array}$ & $\begin{array}{l}\text { NESG } \\
1043 d\end{array}$ & $\begin{array}{l}\text { NESG } \\
1228 \mathrm{a}\end{array}$ & $\begin{array}{l}\text { NESG } \\
1053 a\end{array}$ & $\begin{array}{l}\text { NESG } \\
1054 a\end{array}$ & CXA-3 & CXA-4 \\
\hline $\mathrm{SiO}_{2}$ & 63,91 & 63,44 & 64,33 & 67,61 & 74,32 & 61,81 & 62,72 & 73,75 & 62,71 & 49,72 & 50,44 \\
\hline $\mathrm{TiO}_{2}$ & 1,004 & 0,85 & 0,832 & 0,888 & 0,698 & 0,659 & 0,85 & 0,727 & 0,98 & 0,861 & 1,104 \\
\hline $\mathrm{Al}_{2} \mathrm{O}_{3}$ & 16,16 & 16,23 & 16,61 & 16,69 & 13,18 & 16 & 14,99 & 11,33 & 15,73 & 14,26 & 14,04 \\
\hline $\mathrm{Fe}_{2} \mathrm{O}_{3}$ & 7,89 & 7,22 & 6,65 & 6,62 & 4,38 & 5,38 & 6,18 & 5,22 & 7,95 & 12,08 & 12,08 \\
\hline $\mathrm{MnO}$ & 0,118 & 0,128 & 0,126 & 0,091 & 0,027 & 0,071 & 0,11 & 0,073 & 0,145 & 0,200 & 0,200 \\
\hline $\mathrm{MgO}$ & 3,3 & 3,17 & 2,98 & 1,01 & 1,33 & 2,81 & 2,67 & 1,6 & 3,61 & 8,07 & 7,79 \\
\hline $\mathrm{CaO}$ & 1,6 & 1,99 & 1,76 & 0,51 & 0,25 & 4,29 & 4,46 & 1,4 & 2,43 & 11,80 & 11,40 \\
\hline $\mathrm{Na}_{2} \mathrm{O}$ & 1,29 & 2,3 & 2,56 & 0,82 & 0,18 & 4,13 & 2,01 & 1,14 & 2,33 & 1,71 & 1,79 \\
\hline $\mathrm{K}_{2} \mathrm{O}$ & 2,85 & 2,7 & 2,36 & 3,35 & 3,1 & 2,33 & 3,06 & 2,73 & 2,55 & 0,35 & 0,17 \\
\hline $\mathrm{P}_{2} \mathrm{O}_{5}$ & 0,114 & 0,201 & 0,175 & 0,13 & 0,056 & 0,235 & 0,171 & 0,117 & 0,235 & 0,067 & 0,070 \\
\hline LOI & 0,94 & 0,84 & 0,76 & 1,54 & 1,62 & 1,58 & 2,12 & 0,44 & 0,24 & 0,67 & 0,67 \\
\hline Total & 99,176 & 99,069 & 99,143 & 99,259 & 99,141 & 99,295 & 99,341 & 98,527 & 98,91 & 99,79 & 99,75 \\
\hline $\mathrm{Ba}$ & 801 & 542 & 518 & 671 & 543 & 1450 & 352 & 702 & 603 & 147 & 31 \\
\hline $\mathrm{Ce}$ & 25 & 60 & 41 & 86 & 81 & 74 & 84 & 50 & 50 & $<18$ & $<18$ \\
\hline $\mathrm{Cl}$ & $<15$ & $<15$ & $<15$ & $<15$ & $<15$ & $<15$ & $<15$ & $<15$ & $<15$ & 222 & 386 \\
\hline $\mathrm{Co}$ & 11 & 19 & 14 & 8 & 11 & 17 & 15 & 13 & 21 & 44 & 51 \\
\hline $\mathrm{Cr}$ & 78 & 119 & 115 & 78 & 65 & 38 & 83 & 192 & 168 & 256 & 248 \\
\hline $\mathrm{Cu}$ & 16 & 34 & 34 & 25 & 24 & 16 & 28 & 29 & 32 & 47 & 76 \\
\hline $\mathrm{F}$ & 959 & 929 & 733 & 647 & 512 & 809 & 1338 & 681 & 1200 & $<223$ & $<223$ \\
\hline $\mathrm{Ga}$ & 23 & 20 & 20 & 22 & 19 & 19 & 20 & 14 & 20 & 17 & 16 \\
\hline $\mathrm{La}$ & $<14$ & 24 & 16 & 28 & 40 & 31 & 39 & 28 & 32 & 71 & 20 \\
\hline $\mathrm{Nb}$ & 15 & 10 & 9 & 20 & 10 & 5 & 15 & 11 & 9 & 9 & 9 \\
\hline $\mathrm{Nd}$ & $<22$ & $<22$ & 24 & $<22$ & 35 & 28 & 31 & 40 & 30 & 171 & 38 \\
\hline $\mathrm{Ni}$ & 17 & 62 & 56 & 21 & 26 & 22 & 44 & 35 & 67 & 124 & 117 \\
\hline $\mathrm{Pb}$ & 29 & 17 & 12 & 26 & 17 & 13 & 19 & 18 & 15 & 16 & 32 \\
\hline $\mathrm{Rb}$ & 135 & 94 & 73 & 146 & 129 & 56 & 129 & 95 & 88 & 4 & $<2$ \\
\hline $\mathrm{S}$ & $<100$ & $<100$ & $<100$ & $<100$ & $<100$ & $<100$ & $<100$ & $<100$ & $<100$ & $<100$ & $<100$ \\
\hline $\mathrm{Sc}$ & 17 & 17 & 14 & 11 & 6 & 12 & 16 & 12 & 19 & 44 & 45 \\
\hline $\mathrm{Sr}$ & 73 & 170 & 194 & 111 & 61 & 813 & 240 & 139 & 212 & 145 & 180 \\
\hline Th & 19 & 11 & 4 & 17 & 11 & 10 & 17 & 13 & 11 & 3 & 4 \\
\hline $\mathrm{U}$ & $<3$ & $<3$ & $<3$ & $<3$ & $<3$ & $<3$ & $<3$ & $<3$ & $<3$ & 6 & 5 \\
\hline $\mathrm{V}$ & 119 & 146 & 132 & 91 & 81 & 94 & 110 & 79 & 163 & 300 & 324 \\
\hline $\mathrm{Y}$ & 25 & 33 & 33 & 35 & 13 & 12 & 36 & 36 & 35 & 29 & 48 \\
\hline $\mathrm{Zn}$ & 115 & 120 & 104 & 66 & 79 & 65 & 93 & 59 & 115 & 96 & 84 \\
\hline $\mathrm{Zr}$ & 282 & 189 & 191 & 285 & 245 & 166 & 184 & 342 & 204 & 48 & 57 \\
\hline
\end{tabular}

Grupo Carrancas.

ASSINATURA GEOQUÍMICA Análises químicas representativas das unidades litoestratigáficas da Nappe Andrelândia são apresentadas na Tabela 2. Para comparação, são também apresentadas análises de granulitos de derivação metassedimentar da Klippe Aiuruoca e de granada-biotita xistos do Grupo Carrancas (AL5 de Paciullo et al. 2003).

Os diagramas de variação apresentados na Figura 9 utilizam o teor de $\mathrm{SiO}_{2}$ como discriminante. $\mathrm{O}$ índice de maturidade de sedimentos $\left(\mathrm{IMA}=\mathrm{SiO}_{2} /\right.$ $\left.\left(\mathrm{SiO}_{2}+\mathrm{Al}_{2} \mathrm{O}_{3}\right)\right)$ também foi usado como discriminante, e mostra forte correlação com a sílica; as variações dos diversos óxidos são semelhantes utilizando-se o IMA ou o teor de $\mathrm{SiO}_{2}$ como discriminante.

Os granada-biotita xistos homogêneos do Xisto Santo Antônio têm composição de grauvaca, e elevadas razões $\mathrm{Na}_{2} \mathrm{O} / \mathrm{K}_{2} \mathrm{O}$; a correlação negativa entre $\mathrm{N} / \mathrm{K} \mathrm{e} \mathrm{A} /$ CNK reflete uma variação contínua entre as proporções dos componentes pelítico e psamítico (Fig. 9). O caráter homogêneo dessas rochas se reflete em pequenas variações nos teores de $\mathrm{SiO}_{2}(63-68 \%), \mathrm{CaO}, \mathrm{K}_{2} \mathrm{O}$ e $\mathrm{Na}_{2} \mathrm{O}$ (todos entre 2 e 3\%), $\mathrm{Fe}_{2} \mathrm{O}_{3}(6-8 \%), \mathrm{MgO}(3-3,5 \%)$, e na razão $\mathrm{Na}_{2} \mathrm{O} / \mathrm{K}_{2} \mathrm{O}(1-1,5)$.

Os metapelitos das outras duas unidades da 
Nappe Andrelândia se distinguem pelo ASI (índice de saturação em alumínio) caracteristicamente mais elevado, que é acompanhado de menores teores de $\mathrm{Ca}$, $\mathrm{Mg}, \mathrm{Fe}$, metais de transição e $\mathrm{Sr}$, entre outros (Fig. 9). Alguns contrastes químicos sistemáticos existem entre essas duas unidades, com destaque para o caráter mais francamente peraluminoso de um grupo significativo de amostras do Xisto Serra da Boa Vista, acompanhado por teores mais baixos de $\mathrm{Ca}$.

Os biotita xistos Carrancas cobrem um amplo intervalo de $\mathrm{SiO}_{2}(62-84 \%)$, mas são em geral pouco variados em termos de ASI; algumas amostras exibem as razões $\mathrm{Na}_{2} \mathrm{O} / \mathrm{K}_{2} \mathrm{O}$ mais elevadas de todo o conjunto $(>1,5)$. Essas mesmas amostras se distinguem claramente dos xistos Santo Antônio com teores semelhantes de sílica por seu baixo conteúdo de metais de transição como $\mathrm{Cr}$ e Ni e pelo $\mathrm{Sr}$ mais elevado.

As poucas amostras de granulitos da Klippe Aiuruoca analisadas mostram superposição composicional com os metawackes e metapelitos da Nappe Andrelândia, como já relatado por Garcia et al. (2004) para os granulitos Três Pontas-Varginha. Algumas amostras com teores de sílica semelhantes aos do Xisto Santo Antônio se destacam por seus teores de metais de transição ainda mais elevados.

Foram também analisadas rochas metabásicas de caráter retro-eclogítico da Nappe Liberdade. A geoquímica de elementos maiores permite classificá-las como equivalentes a basaltos de caráter toleítico (Fig. 10). Em diagramas de discriminação tectônica que utilizam elementos traços pouco móveis, como $\mathrm{Ti}, \mathrm{Zr}, \mathrm{Nb}$ e Y (Pearce \& Cann 1973, Meschede 1986), essas rochas se situam preferencialmente no campo dos basaltos de assoalho oceânico (Fig. 10).

IDADE DA DEPOSIÇÃO Do granada-biotita xisto homogêno, litotipo dominante do Xisto Santo Antônio, foram analisados cristais detríticos de zircão em amostra da região de Serranos (MG), que forneceram um resultado de $673 \pm 25 \mathrm{Ma}$ (Campos Neto et al. 2004a), compatíveis com os valores relatados por U.G.Cordani (com.verbal) entre 960 e $632 \mathrm{Ma}$, para os grãos detríticos de amostra do mesmo afloramento, analisados por SHRIMP. Admite-se assim, um período máximo de 20 Ma para a sedimentação, de idade no Ediacariano, para essa unidade litoestratigráfica intermediária da Nappe Andrelândia, metamorfisada a $\sim 610 \mathrm{Ma}$.

$\mathrm{O}$ metabasalto toleítico retro-eclogítico da Nappe Liberdade, afloramento estudado por Campos Neto \& Caby (1999), possui cristais bi-piramidados de zircão, que analisados por $\mathrm{U}_{-} \mathrm{Pb}_{\text {SHRIMP }}$ (Campos Neto et al. $2004 \mathrm{~b}$ ), forneceram idade ${ }^{206} \mathrm{~Pb} / 238 \mathrm{U}$, pré-metamórfica de $669 \pm 25 \mathrm{Ma}$, interpretada como episódio magmático do Criogeniano tardio, penecontemporâneo a sedimentação pelítica.

DISCUSSÃO E CONCLUSÕES O Sistema de Nappes Andrelândia representa uma pilha alóctone, metamorfisada em fácies anfibolito de alta pressão, com registros de fácies eclogito e que grada, em sua re- taguarda, para migmatitos relacionados a uma descompressão para a zona da sillimanita. Granulitos pelíticos de alta pressão caracterizam o alóctono superior, em um padrão metamórfico invertido, controlado por limites tectônicos. As principais estruturas do domínio oriental desse sistema são: a Nappe Andrelândia, inferior; a Nappe Liberdade, intermediária, e a Nappe Pouso Alto, superior (com as Klippen Aiuruoca, Carvalhos e Serra da Boa Vista), que registram um transporte mínimo de $120 \mathrm{~km}$ para E-NE.

Um importante limite tectono-metamórfico separa o Sistema de Nappes Andrelândia (terrenos engajados na subducção continental) do Sistema de Cavalgamentos Carrancas (pilha colisional com gradiente metamórfico barroviano).

A idade $\mathrm{U}-\mathrm{Pb}$ em monazita de $c a .610$ Ma registra o pico metamórfico, na zona da cianita, nas nappes Andrelândia e Liberdade. O valor mais jovem (605 Ma) obtido na Nappe Andrelândia, na zona da cianita-sillimanita, sugere que os domínios metamórficos submetidos ao processo de descompressão isotérmica para a zona da sillimanita podem exibir uma maior taxa relativa de resfriamento. Para o Sistema de Cavalgamentos Carrancas, a monazita indica idades em $\sim 580 \mathrm{Ma}$ (Valeriano et al. 2004).

Na Nappe Andrelândia três unidades litoestratigráficas foram mapeadas como formações e denominadas, da base para o topo, Xisto Rio Capivari (xistos pelíticos predominantes), Xisto Santo Antônio (metawackes) e Xisto Serra da Boa Vista (seqüência xisto-quartzítica), perfazendo uma coluna com espessura aparente mínima de $2400 \mathrm{~m}$. Dados isotópicos Sm-Nd, inéditos dos autores, indicam que o metawacke (Xisto Santo Antônio) possui idades-modelo entre 1,16 e $1,38 \mathrm{Ga}$, e $\mathrm{CNd}_{610 \mathrm{Ma}}$ entre $+0,4$ e $-1,7$, indicativos de uma área fonte neoproterozóica juvenil, distinta dos metapelitos, que têm idades-modelo paleoproterozóicas.Os elevados conteúdos de $\mathrm{MgO}$ e metais de transição como $\mathrm{Cr}$ e Ni do Xisto Santo Antônio são também consistentes com áreas-fonte em arco magmático juvenil, provavelmente instalado em um terreno suspeito ou na borda adelgaçada da Placa Paranapanema no Criogeniano tardio. Essa unidade possui, portanto, características de depósitos orogênicos, tipoflysch, de idade edicariano (entre 630 e $610 \mathrm{Ma}$ ).

Xistos pelíticos da Nappe Liberdade (com intercalações de seqüências metavulcanossedimentares) constituem pacote metassedimentar marinho de águas profundas, lateral à coluna da Nappe Andrelândia. Em meio aos micaxistos ocorrem rochas metamáficas (associadas às metaultramáficas), com assinatura química de fundo oceânico, em lascas eclogíticas, que representam um magmatismo basáltico de caráter toleítico de idade Criogeniano tardio ( $670 \mathrm{Ma})$. Assim, a passagem dos metapelitos aos metawackes, além de registrar uma drástica mudança nas condições de sedimentação, pode representar também um hiato temporal, sugerindo a instalação da bacia flysch edicariana sobre um trato sedimentar de águas profundas do fim do Criogeniano.

Os biotita xistos Carrancas, da unidade AL5 de Paciullo et al. (2003), se comparados aos metassedi- 

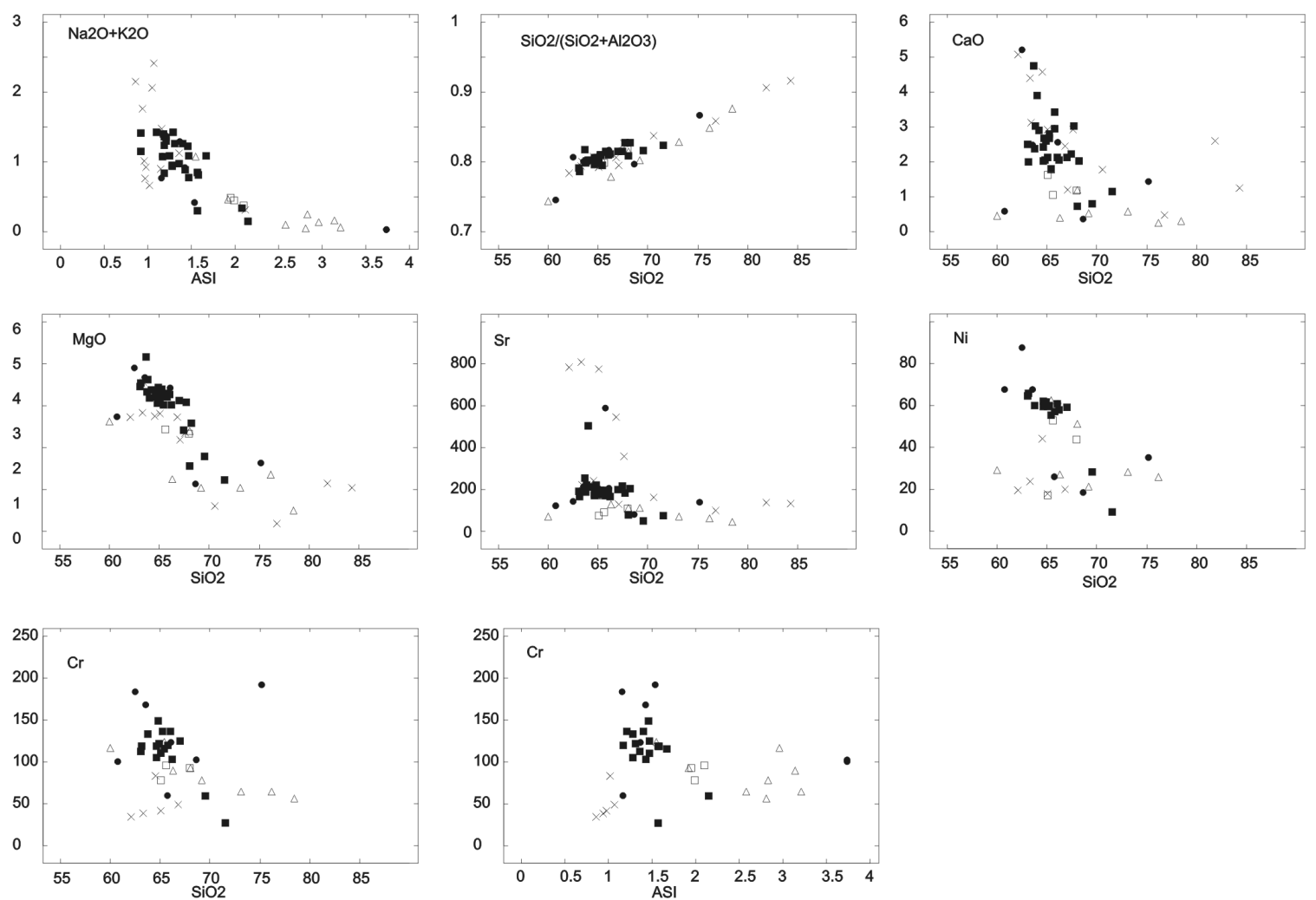

Figura 9 - Diagrama de variação geoquímica para rochas metassedimentares da Nappe Andrelândia. Símbolos: quadrados vazios, Xisto Rio Capivari; Quadrados cheios, Xisto Santo Antônio; triângulos vazios, Xisto Serra da Boa Vista. Granulitos da Klippe Aiuruoca: círculos cheios. Xistos do Grupo Carrancas: " $x$ ”.

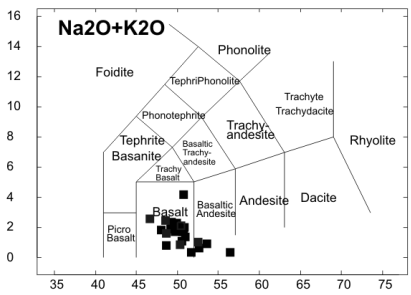

$\mathrm{SiO} 2$
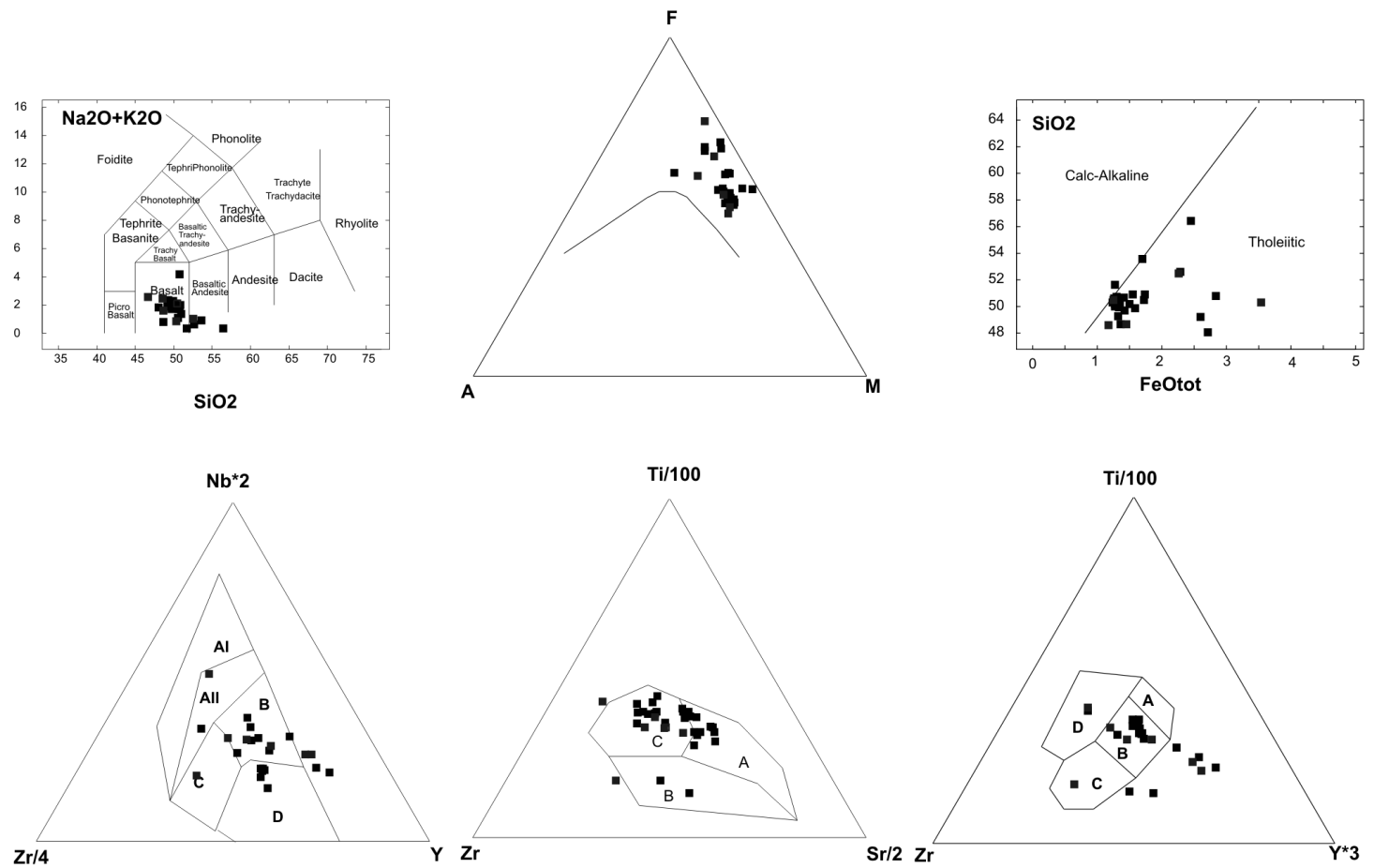

Figura 10 - Diagramas geoquímicos para a classificação tectônica de rochas metabásicas retroeclogiticas da Nappe Liberdade. Campos composicionais: diagrama D) AI=álcali-basaltos intraplacas, $A I I=$ ácali-basaltos e basaltos toleiticos intra-placa; $B=$ MORB enriquecido; $C=$ toleitos intra-placas e basaltos cálcio-alcalinos; $D=M O R B$ normal; diagramas $E$ e $F$ ) A=basaltos de arcos de ilha; $B=$ basaltos cálcio-alcalinos; $C=M O R B ; D=$ basaltos intra-placa. 
mentos do Sistema de Nappes Andrelândia, possuem características de depósitos derivados de áreas-fonte continentais. Exibem assinatura isotópica incompatível com as demais (idades-modelo arqueanas e $\mathrm{CNd}_{610 \mathrm{Ma}}$ fortemente negativo, -18); altas razões $\mathrm{Na} / \mathrm{K}$ e alto conteúdo em Sr, que são sugestivos da contribuição importante de terrenos tipo TTG.

O conteúdo sedimentar e sua sucessão litoestratigráfica, bem como as assinaturas químicas e isotópicas, indicam distintas paleogeografias e diferentes áreas de proveniência para os depósitos dos sistemas de Nappes Andrelândia e de Cavalgamentos Carrancas. Os campos de gradientes metamórficos distintos e incompatíveis também indicam diferentes ambientes colisionais, justapostos por grande aloctonia. Assim, dificilmente poderia ser demonstrada uma continuidade litoestratigráfica entre as unidades desses dois grandes sistemas alóctones, ao contrário do que fica implícito no conceito de Me- gassequência Andrelândia (Ribeiro et al. 1995, Paciullo 1997, Paciullo et al. 2000). O empilhamento litoestratigráfico no interior da Nappe Andrelândia e a correlação, no mesmo ambiente tectônico, com as seqüências com registro de fácies de águas mais profundas da Nappe Liberdade, ou de mesma assinatura geoquímica (Nappe Pouso Alto e Klippen), permitem restringir a denominação de Grupo Andrelândia, como inicialmente sugerido por Trouw et al. (1983), às unidades identificadas, neste trabalho, ao Sistema de Nappes Andrelândia.

Agradecimentos Este trabalho foi possível graças aos projetos FAPESP (98/15624-8 e 02/03131-4) do primeiro autor e dos grants de pesquisa do $\mathrm{CNPq}$ de todos os autores. Somos gratos pela leitura cuidadosa e sugestões dos relatores anônimos e a Dra. Mônica M. Perrotta pela edição de figuras em um sistema de informações georreferenciado.

\section{Referências}

Almeida S. \& Junho M.C.B. 1993. Geoquímica de corpos ultramáficos na região de Liberdade, MG. In: UERJ-SBG, Simpósio de Geologia do Sudeste, 3, Rio de Janeiro, Atas, p. 125-131.

Almeida S. 1993. Metamorfismo de corpos ultramáficos na região de Liberdade, MG. In: UERJ-SBG, Simp. de Geologia do Sudeste, 3, Rio de Janeiro, Atas, p. 132-137.

Braga I.F. 2002. Análise da deformação de rochas infracrustais da região de Cristina e Itajubá-MG. Tese de Doutorado, Universidade Estadual Paulista, 197 p.

Brito Neves B.B., Campos Neto M.C. \& Fuck R.A. 1999. From Rodinia to Western Gondwana: An approach to the Brasiliano-Pan African Cycle and orogenic collage. Episodes, 22:155-166.

Campos Neto M.C. \& Caby R. 1999. Tectonic constrain on Neoproterozoic hig-pressure metamorphism and nappe system south of São Francisco craton, southeast Brazil. Precambrian Res., 97:3-26.

Campos Neto M.C. \& Caby R. 2000. Lower crust extrusion and terrane accretion in the Neoproterozoic nappes of southeast Brazil. Tectonics, 19:669-687.

Campos Neto M.C. 2000. Orogenic Systems from Southwestern Gondwana: an approach to Brasiliano-Pan African Cycle and orogenic collage in Southeastern Brazil. In: U.G. Cordani, E.J. Milani, A. Thomaz Filho \& D.A. Campos (eds.) Tectonic Evolution of South America. Rio de Janeiro, Brazil, p. 335-365.

Campos Neto M.C., Basei M.A.S., Vlach S.R.F., Caby R., Szabó G.A.J. \& Vasconcelos P. 2004a. Migração de orógenos e superposição de orogêneses: Um esboço da colagem Brasiliana no sul do Cráton do São Francisco, SE - Brasil. Rev. Inst. Geoc. USP, Geologia USP, Série Cientifica, 4(1):13-40.

Campos Neto M.C., Basei M.A.S., Janasi V.A. \& Nutman A.P. 2004 b. Idades $\mathrm{U}-\mathrm{Pb}_{\text {SHRIMP }}$ de retro-eclogito do Terreno Andrelândia. In: IGc-USP, Simpósio 40 Anos de Geocronologia no Brasil, São Paulo, p. 67.

Faure G. 1977. Principles of Isotope Geology. Smith-Wyllie
Intermediate Geology Series, J. Wiley \& Sons, 464 p.

Fetter A.H., Hackspacker P.C., Ebert H.D., Dantas E.L. \& Costa A.C.D. 2001. New Sm/Nd and U/Pb geochronological constraints on the Archean to Neoproterozoic evolution of the Amparo basement complex of the central Ribeira belt, Southeastern Brazil. In: South American Synposium on Isotope Geology, 3, Extend Abstracts, CD-ROM.

Garcia M.G.M., Campos Neto M.C. \& Janasi V.A. 2004. Proveniência e ambientação tectônica de metassedimentos de alto grau: Nappe Três Pontas-Varginha, sul do Cráton do São Francisco. Rev. Bras. Geoc., 31(1):49-58.

Heilbron M. 1985. O metamorfismo da área de Itutinga-Madre de Deus de Minas - MG. In: Simpósio de Geologia de Minas Gerais, 3, Anais, p. 219-233.

Jost H., Theodoro S.M.C.H., Figueiredo A.M.G. \& Boaventura G.R. 1996. Propriedades geoquímicas e proveniência de rochas metassedimentares detríticas arquenas dos greenstone belts de Crixás e Guarinos, Goiás. Rev. Bras. Geoc., 26:151-166.

Junho M.C.B. 1993. Leucogranitos e migmatitos entre Liberdade e Alagoa, sul de MG. In: UERJ-SBG, Simp.de Geologia do Sudeste, 3, Rio de Janeiro, Atas, p. 138-143.

Junho M.C.B. 1995. Leucogranites and related migmatites, southern Minas Gerais and southwestern Rio de Janeiro States, Brazil. An. Acad. Bras. Ciênc., 67(4):497-515.

Junho M.C.B. \& Mendes J.C. 2000. Diatexitic gneisses of the Andrelândia Group, southern Minas Gerais, Brazil: Geological and geochemical constraints. Rev. Bras. Geoc., 30(3):353-357.

Ludwig, K. R. 1999. Isoplot/Ex 2.01: A geochronological toolkit for Microsoft Excel. Berkeley Geochronology Center Special Publication 1a, $50 \mathrm{p}$.

Mantovani M.S.M. \& Brito Neves B.B. 2005. The Paranapanema Lithospheric Block: Its importance for Proterozoic (Rodinia, Gondwana) Supercontinent theories. Gondwana Res., 8(3):303-315.

Mechede M. 1986. A method of discriminating between dif- 
ferent types of mid-ocean ridge basalts and continental tholeiites with the Nb-Zr-Y diagram. Chem. Geol., 56: 207-218.

McLennan S.M. \& Taylor S.R. 1991. Sedimentary rocks and crustal evolution: tectonic setting and secular trends. $J$. Geol., 99:1-21.

Nesbitt H.W \& Young G.M. 1982. Early Proteozoic climates and plate motions inferred from major chemistry of lutites. Nature, 299:715-717.

Paciullo F.V.P. 1997. A Seqüência Deposicional Andrelândia. Tese de Doutorado, Instituto de Geociências, Universidade Federal do Rio de Janeiro, 248 p.

Paciullo F.V.P., Ribeiro A., Andreis R.R. \& Trouw R.A.J. 2000. The Andrelândia basin, a Neoproterozoic intraplate continental margin, southern Brasilia belt. Rev. Bras. Geoc., 30:200-2002.

Paciullo F.V.P., Trouw R.A.J. \& Ribeiro A. 2003. Geologia da Folha Andrelândia. In: A.C. Pedrosa-Soares, C.M. Noce, R.A.J. Trouw \& M. Heilbron (orgs.) Geologia e Recursos Minerais do Sudeste Mineiro, Projeto Sul de Minas, v.1, p. 84-120.

Pearce J.A. \& Cann J.R. 1973. Tectonic settings of basic volcanic rocks determined using trace-element analyses. Earth Plan. Sci. Lett., 19:290-300.

Peternel R., Trouw R.A.J. \& Schmitt R.S. 2005. Interferência entre duas faixas móveis neoproterozóicas: o caso das Faixas Brasília e Ribeira no sudeste do Brasil.. Rev. Bras. Geoc., 35:297-310.

Ribeiro A. \& Heilbron M. 1982. Estratigrafia e metamorfismo dos Grupos Carrancas e Andrelândia, sul de Minas Gerais. In: Congresso Brasileiro de Geologia, 32, Anais, v.1, p. 177-186.

Ribeiro A., Trouw R.A.J., Andreis R.R., Paciullo F.V.P. \& Valença J. 1995. Evolução das bacias proterozóicas e o termo-tectonismo Brasiliano na margem sul do Cráton do São Francisco. Rev. Bras. Geoc., 25:235-248.

Ribeiro A., Paciullo F.V.P., Noce C.M., Valeriano C.M., Valença J.G., Ávila C.A., Trouw R.A.J. \& Silva M.A. 2002a. Geologia da Folha São João Del Rei. In: A.C. Pedrosa-Soares, C.M. Noce, R.A.J. Trouw \& M. Heilbron (orgs.) Geologia e Recursos Minerais do Sudeste Mineiro, Projeto Sul de Minas, v.1, p. 521-622.

Ribeiro A., Paciullo F.V.P., Noce C.M., Valeriano C.M., Valença J.G., Ávila C.A., Trouw R.A.J. \& Silva M.A. 2002b. Mapa Geológico Folha São João Del Rei, escala 1:100.000. COMIG, UFRJ, UFMG, Projeto Sul de Minas - Etapa I.

Rodrigues S.W.O. 2003. Contexto geológico e estrutural da Zona de Cisalhamento Liberdade (MG). Dissertação de Mestrado, IGc, Universidade de São Paulo, 103 p.

Santos, L.P. 2004. Trajetórias metamórficas de ambientes colisionais: Domínios frontais das Nappe Aiuruoca-Andrelândia e Lima Duarte, borda sul do Cráton do São Francisco, Minas Gerais. Dissertação de Mestrado, Instituto de Geociências, Universidade de São Paulo, 90 p.

Santos L.P., Campos Neto M.C. \& Carvalho C.H.G. 2004. Metamorphic path constrained by metapelitic rocks from the inner Aiuruoca-Andrelândia Nappe, Southern of the São Francisco craton, SE Brazil. J. South Am. Earth Sci., 16:725-741.
Steiger R.H. \& Jäger E. 1977. Subcommission on geochronology: Convention on the use of decay constants in geo- and cosmochronology. Earth Plan. Sci. Lett., 36(3):359-362.

Trouw R.A.J., Paciullo F.V.P., Chrispim S.J. \& Dayan H. 1982. Análise da deformação numa área a SE de Lavras, Minas Gerais. In: Congresso Brasileiro de Geologia, 32, Salvador, Anais, v.1, p. 187-198.

Trouw R.A.J., Ribeiro A. \& Paciullo F.V.P. 1983. Geologia estrutural dos Grupos São João Del Rei, Carrancas e Andrelândia, Sul de Minas Gerais. An. Acad. Bras. Ciênc., 55(1):71-85.

Trouw R.A.J., Ribeiro A. \& Paciullo F.V.P. 1986. Contribuição à geologia da Folha Barbacena - 1:250.000. In: Cong. Brasileiro de Geologia, 34, Goiânia, Anais, p. 974-986.

Trouw R.A.J. 1992. Evolução tectônica ao sul do Cráton do São Francisco, baseada em análise metamórfica. In: Cong. Brasileiro Geologia, 37, S. Paulo, Anais, p. 327.

Trouw R.A.J. \& Pankhurst R.J. 1993. Idades radiométricas ao sul do Cráton do São Francisco: Região da folha Barbacena, Minas Gerais. In: Simpósio sobre o Cráton do São Francisco, 2, Salvador, Anais, p. 260-262.

Trouw R.A.J., Paciullo F.V.P. \& Ribeiro A. 1998. Tectonic significance of Neoproterozoic high pressure granulites in southern Minas Gerais. In: International Conference on Basement Tectonics, 14, Ouro Preto, Anais, p. 69-71.

Trouw R.A.J., Heilbron M., Ribeiro A., Paciullo F., Valeriano C.M., Almeida J.C.H., Tupinambá M. \& Andreis R.R. 2000. The central segment of Ribeira Belt. In: In: U.G. Cordani, E.J. Milani, A. Thomaz Filho \& D.A. Campos (eds.) Tectonic Evolution of South America. Rio de Janeiro, Brazil, p. 287-310.

Trouw, R.A.J., Junho, M.C.B., Ribeiro, Paciullo, F.V.P., Almeida, M.E. \& Valeriano C.M. 2002a. Mapa Geológico Folha Pouso Alto, escala 1:100.000. COMIG, UFRJ, UFMG, Projeto Sul de Minas - Etapa I.

Trouw R.A.J., Paciullo F.V.P., Ribeiro A., Bittar S. \& Almeida J.C.H. 2002b. Mapa Geológico Folha Caxambu, escala 1:100.000. COMIG, UFRJ, UFMG, Projeto Sul de Minas-Etapa I.

Vail P.R., Mitchum Jr. R.M. \& Thompson S. 1977. Seismic stratigraphy and global changes in sea level. Part 3: Relative change in sea level from coast onlap. In: C.E. Payton (ed.) Seismisc stratigraphy application to hydrocarbon exploration. Americam Association of Petroleum Geologists, Memoir, v.26, p. 63-82.

Valeriano C.M., Machado N., Simonetti, A., Valladares C.S., Seer H.J. \& Simões L.S.A. 2004. U-Pb geochronology of the southern Brasilia belt (SE-Brazil): Sedimentary provenance, Neoproterozoic orogeny and assembly of West Gondwana. Precambrian Res., 130:27-55.

Vilela L.G.G. 2000. Petrografia, geotermobarometria e evolução metamórfica de granulitos básicos de alta pressão e rochas transicionais para fácies eclogito na região de Lima Duarte, $M G$. Dissertação de Mestrado, Instituto de Geociências, Universidade de São Paulo, 180 p.

Manuscrito CSF-09 Submetido em 31 de maio de 2006 Aceito em 24 de novembro 2006 